\title{
Correction to: Systematic review and meta- analysis of case-crossover and time-series studies of short term outdoor nitrogen dioxide exposure and ischemic heart disease morbidity
}

David M. Stieb ${ }^{1,2^{*}}$, Carine Zheng ${ }^{2}$, Dina Salama², Rania Berjawi ${ }^{2}$, Monica Emode ${ }^{3}$, Robyn Hocking ${ }^{4}$, Ninon Lyrette ${ }^{5}$, Carlyn Matz ${ }^{5}$ Eric Lavigne ${ }^{2,5}$ and Hwashin H. Shin ${ }^{1,6}$

Correction to: Environ Health 2020 May 1; 19: 47 https://doi.org/10.1186/s12940-020-00601-1.

Following publication of the original article [1], the authors identified an error in the last letter of the author name of Rania Berjawi.

Incorrect name:

Rania BerjawI

Correct name:

Rania Berjawi

The author group has been updated above and the original article [1] has been corrected.

\footnotetext{
Author details

${ }^{1}$ Environmental Health Science and Research Bureau, Health Canada, 420-757 West Hastings St. - Federal Tower, Vancouver, BC V6C 1A1, Canada. ${ }^{2}$ School of Epidemiology and Public Health, University of Ottawa, Ottawa, Canada. ${ }^{3}$ School of Population and Public Health, University of British Columbia, Vancouver, Canada. ${ }^{4}$ Learning, Knowledge and Library Services, Health Canada, Ottawa, Canada. ${ }^{5}$ Water and Air Quality Bureau, Health Canada, Ottawa, Canada. ${ }^{6}$ Department of Mathematics and Statistics, Queen's University, Kingston, Canada.
}

The original article can be found online at https://doi.org/10.1186/s12940020-00601-1.

*Correspondence: dave.stieb@canada.ca

${ }^{1}$ Environmental Health Science and Research Bureau, Health Canada, 420-757 West Hastings St. - Federal Tower, Vancouver, BC V6C 1A1, Canada

${ }^{2}$ School of Epidemiology and Public Health, University of Ottawa, Ottawa, Canada

Full list of author information is available at the end of the article
Published online: 24 July 2020

\section{Reference}

1. Stieb DM, et al. Systematic review and meta-analysis of case-crossover and time-series studies of short term outdoor nitrogen dioxide exposure and ischemic heart disease morbidity. Environ Health. 2020;19:47. https://doi.org/ 10.1186/s12940-020-00601-1.

(c) The Author(s). 2020 Open Access This article is licensed under a Creative Commons Attribution 4.0 International License, which permits use, sharing, adaptation, distribution and reproduction in any medium or format, as long as you give appropriate credit to the original author(s) and the source, provide a link to the Creative Commons licence, and indicate if changes were made. The images or other third party material in this article are included in the article's Creative Commons licence, unless indicated otherwise in a credit line to the material. If material is not included in the article's Creative Commons licence and your intended use is not permitted by statutory regulation or exceeds the permitted use, you will need to obtain permission directly from the copyright holder. To view a copy of this licence, visit http://creativecommons.org/licenses/by/4.0/. The Creative Commons Public Domain Dedication waiver (http://creativecommons.org/publicdomain/zero/1.0/) applies to the data made available in this article, unless otherwise stated in a credit line to the data. 